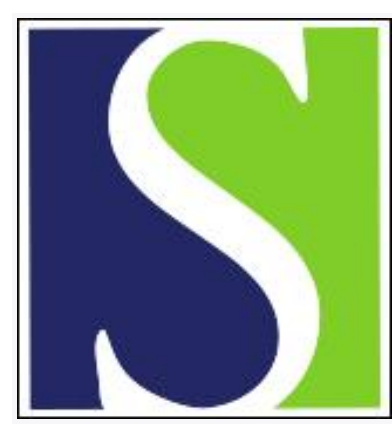

Scand J Work Environ Health 1997;23(6):414-420

https://doi.org/10.5271/sjweh.263

Issue date: Dec 1997

Urinary naphthols as an indicator of exposure to naphthalene by Bieniek G

Key terms: biological monitoring; naphthalene exposure; urinary metabolite

This article in PubMed: www.ncbi.nlm.nih.gov/pubmed/9476804

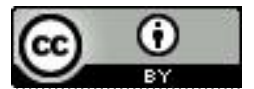




\title{
Urinary naphthols as an indicator of exposure to naphthalene
}

\author{
by Grażyna Bieniek, $P h D^{1}$
}

\begin{abstract}
Bieniek G. Urinary naphthols as an indicator of exposure to naphthalene. Scand J Work Environ Health 1997; 23(6):414-20.

Objective The relationship between exposure to naphthalene and urinary excretion of naphthols was examined.

Methods Concentrations of naphthalene and naphthols in breathing-zone air during a workshift and 1-naphthol and 2-naphthol in urine collected after the workshift were determined for 102 male workers. Gas chromatography with a flame ionization detector (GC-FID) was used to determine the air concentration. Urine naphthols were extracted after acid hydrolysis by solid-phase extraction and separated by the GC-FID method. Naphthalene homologues in air and their metabolites in urine samples were identified by gas chromatographymass spectrometry.

Results 1-Naphthol, 2-naphthol and 1,4-naphthoquinone were identified in the urine samples. The timeweighted average concentrations of naphthalene and naphthols in the breathing-zone air showed that the exposure level of the workers was rather low. The geometric mean values were as follows: 0.77 and $0.87 \mathrm{mg} / \mathrm{m}^{3}$ for naphthalene, 0.016 and $0.034 \mathrm{mg} / \mathrm{m}^{3}$ for 1-naphthol, 0.012 and $0.067 \mathrm{mg} / \mathrm{m}^{3}$ for 2-naphthol during tar distillation and naphthalene oil distillation, respectively. The corresponding urinary concentrations of $1-$ and 2-naphthols were 693.1 and $264.4 \mu \mathrm{mol} / \mathrm{mol}$ and 264.4 and $297.7 \mu \mathrm{mol} / \mathrm{mol}$ creatinine, respectively. The correlation coefficients between the naphthol concentrations in urine and the breathing-zone air concentrations of naphthalene were statistically significant, varying in the range of $0.64-0.75$ for 1 -naphthol and $0.70-0.82$ for 2-naphthol. There was linear dependence $(r=0.76)$ between the summary concentration of naphthols in urine and the naphthalene concentration in air.

Conclusions Workers in tar distillation and naphthalene distillation are exposed to rather low concentrations of naphthalene and methylated naphthalenes and naphthols. Naphthols and 1,4-naphthoquinone identified in the urine appear to be the products of the hydroxylation of naphthalene present in the breathing-zone air. These findings suggest that the summary concentration of naphthols in urine can be used as a biomarker for naphthalene exposure.
\end{abstract}

Key terms biological monitoring, naphthalene exposure, urinary metabolites.

Naphthalene is used in the production of phthalic anhydride, phthalate plasticizers, resin, phthaleins, and other materials. The distillation and fractionation of coal tar is the most common production process. Naphthalene and the methylated naphthalenes are also found in petroleum products and tobacco smoke (1).

Earlier data have shown that naphthalene can be absorbed by pulmonary (2), gastrointestinal (3), and cutaneous routes (4). In animals naphthalene has been shown to affect hematologic parameters or cause histopathological lesions of the liver (5), carcinogenicity in female mice (6), and cataractogenicity (7). The International Agency for Research on Cancer (1) has determined that naphthalene is not classifiable as a carcinogen to humans. The most common hematologic effect in humans following the ingestion of naphthalene is hemolytic anemia $(3,8)$ and hepatic and neurological effects (8).

The metabolism of naphthalene has been studied in experimental animals $(7,9-12)$. Little information is available pertaining to the metabolism of naphthalene by humans. Naphthalene is effectively metabolized to the toxic compound naphthoquinone $(7,13)$ and 1,2-dihydro-1,2-naphthalenediol (14). An earlier report presented what appeared to be a case of oral ingestion in which the urine of an 18-month-old child was found to contain 1naphthol, 2-naphthol, 1,2-naphthoquinone, and 1,4-naphthoquinone (13).

Naphthol was found in the urine of workers exposed to naphthalene $(15,16)$ and to the insecticide carbaryl

Department of Biochemistry and Biophysics, Silesian Medical Academy, Sosnowiec, Poland.

Reprint requests to: Dr G Bieniek, Department of Biochemistry and Biophysics, Silesian Medical Academy, Jagiellonska 4, 41-200 Sosnowiec, Poland. 
(17), as well as in the urine of animals after the administration of 1-naphthol.

1-Naphthol as a metabolite of naphthalene has been used as an indicator of naphthalene exposure in biological monitoring. Increased urinary levels of 1-naphthol have been measured in several environments for iron foundry workers (18), coke plant workers (15), and assemblers handling creosote-impregnated wood (16). This study aimed at identifying naphthalene homologues and urinary metabolites of workers exposed to naphthalene and investigating the relationship between exposure to naphthalene measured by personal air sampling and the excretion of 1- and 2-naphthols in urine.

\section{Subjects and methods}

Measurements were carried out in a coke plant. The survey was performed on the 4th or 5th day of a workweek. Workers exposed to naphthalene and its homologues were engaged as operators in the tar distillation process (group A) and as operators in the naphthalene oil distillation process (group B). Information about some characteristics of the attendants (age, length of employment, smoking habits) were obtained from self-completed questionnaires (table 1). Unfortunately, better age selection was impossible because of the small number of workers employed in a particular job. The reference group (C) comprised 25 men and 11 women who lived in the same area as the workers, but who were not occupationally exposed.

\section{Air sampling}

Vapor samples of the breathing-zone air of the workers were collected during the workshift. Personal sampling was performed using a battery-operated pump (type AFC 123 Casella Ltd, London) connected to a filter holder attached to the shoulder of the subject. Air was aspirated through the charcoal tubes (cat no 226-01, SKC Inc, Eighty Four, PA, USA) with the flow rate of $0.5 \mathrm{l} / \mathrm{min}$. The sucked air volume was 1801 , and the sampling time was $6 \mathrm{~h}$. The naphthalene was released from the charcoal by treatment with $1 \mathrm{ml}$ of carbon disulfide in an ultrasonic bath for 15 minutes. The amount of the compound in the shorter layer did not exceed $10 \%$ of the compound in the longer one. Otherwise the measurement was repeated.

\section{Naphthalene analysis}

Naphthalene in the air samples was determined gas chromatographically using a capillary column Ultra 2 (crosslinked 5\% phenylmethyl silicone) with an inner diameter of $25 \mathrm{~m} \mathrm{x} 0.32 \mathrm{~mm}$, and a film thickness of $0.52 \mu \mathrm{m}$ (Hewlett-Packard). A gas chromatograph (HP model 5890) equipped with a flame ionization detector (FID) and autoinjector (HP 7673) was used. The gas chromatographic analysis of the carbon disulfide extract was performed as previously described (Cisowska, Lusiak, Siwek, unpublished data). The oven temperature was programmed as follows: $40^{\circ} \mathrm{C}$ for 1 minute, increasing $12^{\circ}$ minute to $140^{\circ} \mathrm{C}$, and held for 2 minutes. The injector and detector temperatures were set at $200^{\circ} \mathrm{C}$ and $220^{\circ} \mathrm{C}$, respectively. Helium gas was used as a carrier with a low of $2 \mathrm{ml} / \mathrm{min}$. The split rate was $1: 75$ and the injection volume was $1 \mu$. The detection limit was $0.06 \mathrm{mg} / \mathrm{m}^{3}$. Accuracy was defined as the percentage derivation between the average concentration obtained from the experiment, and the theoretical concentration was $6 \%$. The average desorption efficiency over the working range of $0.03-0.3 \mu \mathrm{g} / \mathrm{ml}$ varied between 0.5 and 0.56 .

\section{Naphthol analysis}

Air was aspirated at a flow rate of $0.51 / \mathrm{min}$ through kieselgel (kieselgel 40, 0.2-0.5 mm, Fluka). The naphthols were released from the kieselgel by treatment with $1 \mathrm{ml}$ of ethanol. The gas chromatographic (GC) conditions were the same as previously described for the urine analysis (19). The detection limit was $3 \mu \mathrm{g} / \mathrm{m}^{3}$. The desorption efficiency for analytes was higher than 0.93 .

\section{Urine sampling and analysis}

The exposed workers and unexposed reference group were asked to urinate 4 th-hour urine collected at the end of an 8-h shift. The samples were transferred to the analytical laboratory and kept frozen until the analysis. The GC/FID analyses for 1-naphthol and 2-naphthol in urine were carried out as described earlier (19). The 1and 2-naphthol concentrations were corrected for creatinine or specific gravity of 1.024 .

Table 1. Basic characteristics of the coke plant workers and occupationally unexposed subjects.

\begin{tabular}{|c|c|c|c|c|c|c|c|c|c|c|c|}
\hline \multirow[t]{2}{*}{ Group } & \multirow[t]{2}{*}{$\begin{array}{c}\text { Total } \\
\text { number }\end{array}$} & \multirow[t]{2}{*}{$\begin{array}{c}\text { Smokers } \\
\text { (N) }\end{array}$} & \multicolumn{3}{|c|}{ Age (years) } & \multicolumn{3}{|c|}{$\begin{array}{c}\text { Length of } \\
\text { employment (years) }\end{array}$} & \multicolumn{3}{|c|}{$\begin{array}{c}\text { Cigarettes } \\
\text { consumed per day (N) }\end{array}$} \\
\hline & & & Mean & SD & Range & Mean & $\mathrm{SD}$ & Range & Mean & SD & Range \\
\hline Operators of the tar distillation process & 69 & 56 & 41.4 & 8.7 & $20-56$ & 21.2 & 11.6 & $5-41$ & 17.6 & 8.5 & $4-35$ \\
\hline Operators of naphthalene oil distillation process & 33 & 33 & 39.9 & 10.8 & $21-59$ & 17.6 & 10.6 & $3-36$ & 16.2 & 6.5 & $3-40$ \\
\hline Unexposed workers & 36 & 28 & 36.3 & 8.0 & $18-56$ & 14.9 & 9.6 & $5-26$ & 14.1 & 6.3 & $5-20$ \\
\hline
\end{tabular}




\section{Gas chromatographic-mass spectrometric identification}

Gas chromatographic - mass spectrometry (GC-MS) system was employed to separate and identify the components of the air and urine samples. A carbon disulfide extract of air and an ethyl acetate extract of urine were used. Air sampling for the identification of naphthols and for naphthalene was not performed at the same time because of the necessity to use a different adsorbent for naphthalene. Naphthalene and its homologues in air and the metabolites of naphthalene in urine were identified with the same GC-MS conditions as described elsewhere (Bieniek \& Kurkiewicz, submitted for publication).

\section{Results}

The GC-MS analysis of the compounds adsorbed on active carbon revealed the presence of aromatic hydrocarbons, mainly naphthalene and methylated naphthalenes, in the breathing-zone air of the coke plant workers. A representative chromatogram is shown in figure 1. The hydrocarbons were identified as being naphthalene, methyl- and dimethylnaphthalene isomers, and trimethylnaphthalene, biphenyl, and benzo[b]thiophene. These compounds are included in the high-temperature naphthalene fraction of tar. In figure 1 naphthols are not seen because these compounds were adsorbed on silica gel as separate samples. Figure 2 illustrates a chromatogram obtained for samples prepared from the urine of workers engaged as operators of the naphthalene oil distillation process and exposed to naphthalene and its homologues. Three oxygenated naphthalene metabolites isolated from urine were identified as 1-naphthol, 2-naphthol, and 1,4naphthoquinone. In the urine of the exposed workers, 1 (4-hydroxy-3-methoxyphenyl)ethanone and 1,3-dihydro$2 \mathrm{H}$-indol-2-one were identified. The two last-mentioned compounds were also found in the urine of the unexposed subjects, possibly because of the normal metabolic process, as well as because of environmental exposure.

The naphthalene and 1- and 2-naphthol concentrations that were above the analytical detection limits for the air and urine samples were found to be distributed log-normally. Table 2 presents the concentrations of naphthalene in the breathing-zone air and those of 1 - and 2-naphthols in the urine collected from the workers directly after the end of the workshift. The urinary metabolite levels are expressed as observed or corrected for creatinine concentration or corrected for a specific gravity of urine equal to 1.024 . Urine samples with creatinine concentrations below $2.6 \mu \mathrm{mol} / \mathrm{l}$ or above $26 \mu \mathrm{mol} / \mathrm{l}$ and with the specific gravity values below 1.010 and above 1.030 were removed from the analysis. The presence of the 1- and 2-naphthols in the urine of workers is a result of the exposure to naphthalene, as well as to low amounts of naphthols found in the breathing-zone air. Concentrations of the 1- and 2-naphthols in air were about 40 to 60 times lower than the concentrations of naphthalene. Group B comprises workers for which 1- and 2-naphthols were found simultaneously. The percentage of 1 naphthol in the mixture of naphthols (1- and 2-naphthols) differed for subsequent workers, covering the

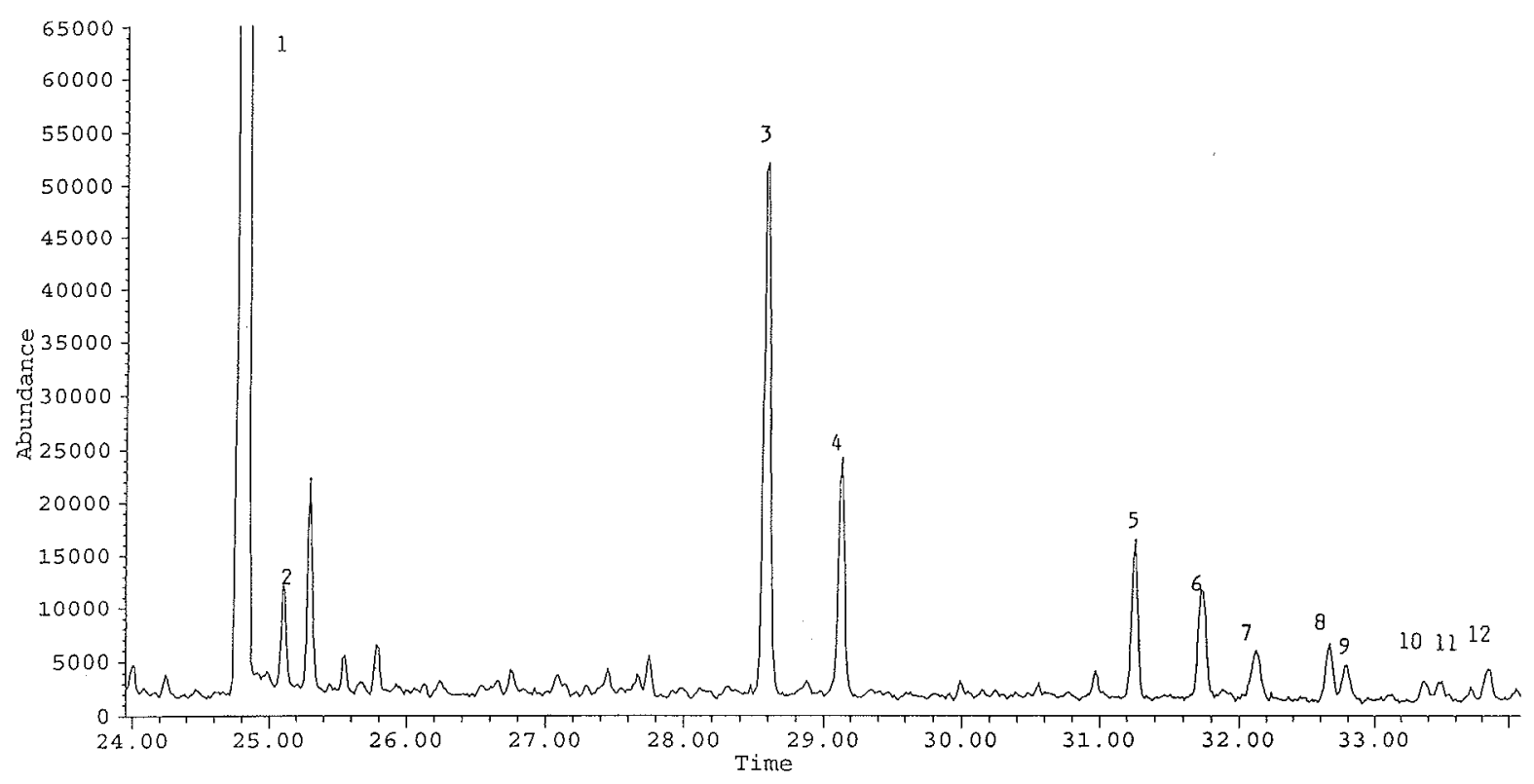

Figure 1. Chromatogram of the aromatic hydrocarbons identified in the breathing-zone air of the workers. (Numbered peaks identified as follows: 1 = naphthalene, 2 = benzo(b)thiophene, $3=1$-methylnaphthalene, $4=2$-methylnaphthalene, $5=$ biphenyl, $6=2$-ethylnaphthalene, $7-11=$ dimethylnaphthalene izomers, 12 = trimethylnaphthalene) 


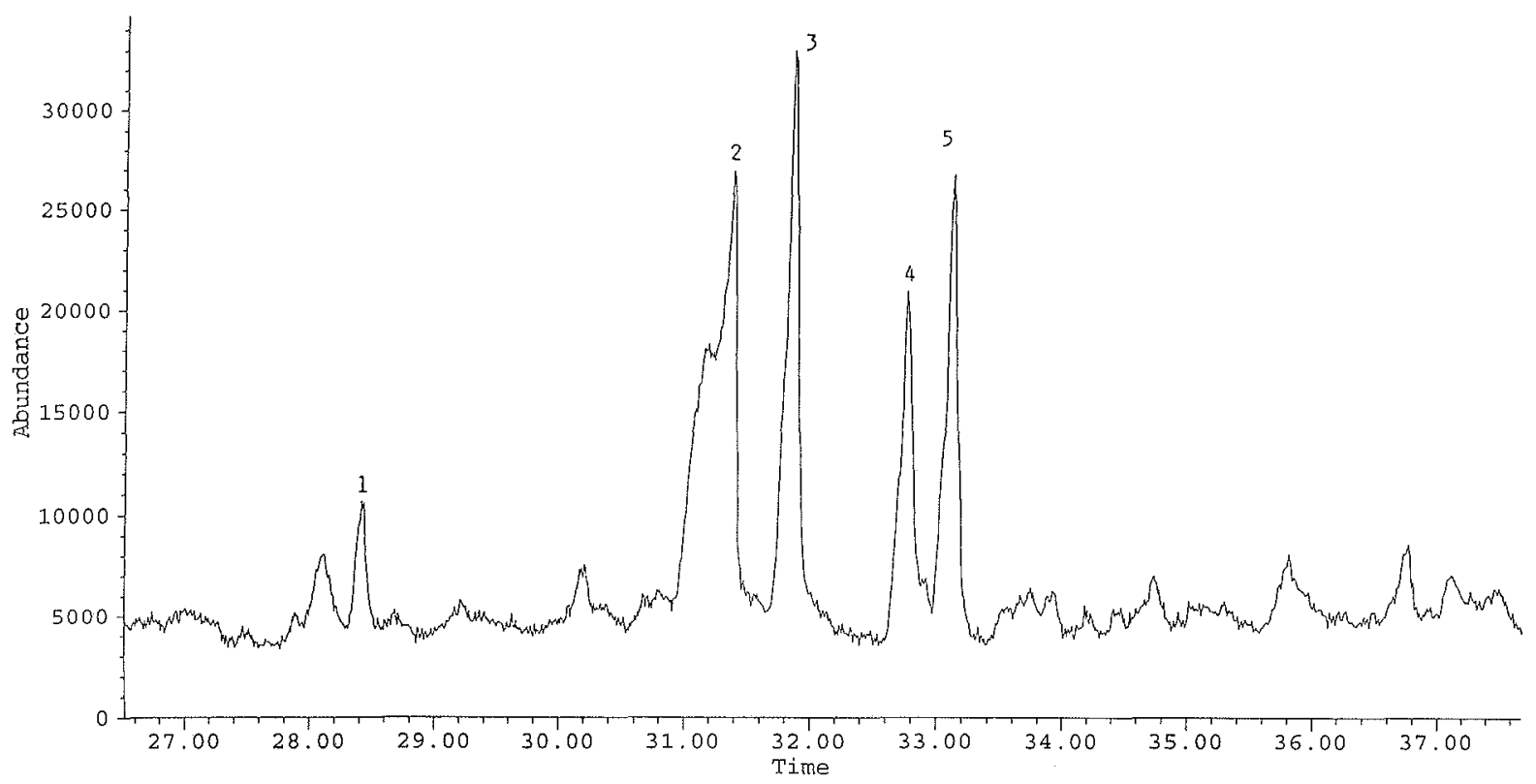

Figure 2. Chromatogram of metabolites isolated from an acid-hydrolyzed urine sample. (Numbered peaks identified as follows: $1=1,4$ naphthoquinone, 2 = 1,3-dihydro-2H-indol-2-one, 3 = 1-(4-hydroxy-3-methoxyphenyl)ethanone, 4 = 1-naphthol, 5 = 2-naphthol)

Table 2. Concentration of naphthalene and naphthols in the breath-zone air and 1-naphthol and 2-naphthol in the urine of the exposed workers and unexposed subjects.

\begin{tabular}{|c|c|c|c|c|c|c|c|c|c|c|c|}
\hline \multirow[t]{3}{*}{ Group } & \multirow[t]{3}{*}{ Exposure } & \multirow[t]{3}{*}{$\begin{array}{l}\text { Workers } \\
(\mathrm{N})\end{array}$} & \multicolumn{2}{|c|}{$\begin{array}{l}\text { Concentration in } \\
\text { breathing } \\
\text { zone air }\left(\mathrm{mg} / \mathrm{m}^{3}\right)\end{array}$} & \multirow[t]{3}{*}{ Metabolite } & \multicolumn{2}{|c|}{$\begin{array}{c}\text { Observed } \\
\text { value }(\mu \mathrm{mol} / \mathrm{l})\end{array}$} & \multicolumn{4}{|c|}{ Value corrected for } \\
\hline & & & \multirow{2}{*}{$\begin{array}{c}\text { Geo- } \\
\text { metric } \\
\text { mean }\end{array}$} & \multirow{2}{*}{$\begin{array}{l}\text { Geo- } \\
\text { metric } \\
\text { SD }\end{array}$} & & \multirow{2}{*}{$\begin{array}{l}\text { Geo- } \\
\text { metric } \\
\text { mean }\end{array}$} & \multirow{2}{*}{$\begin{array}{l}\text { Geo- } \\
\text { metric } \\
\text { SD }\end{array}$} & \multicolumn{2}{|c|}{$\begin{array}{c}\text { Creatinine } \\
(\mu \mathrm{mol} / \mathrm{mol})\end{array}$} & \multicolumn{2}{|c|}{$\begin{array}{l}\text { Specific gravity } \\
\text { (umol/l) }\end{array}$} \\
\hline & & & & & & & & $\begin{array}{c}\text { Geo- } \\
\text { metric } \\
\text { mean }\end{array}$ & $\begin{array}{c}\text { Geo- } \\
\text { metric } \\
\text { SD }\end{array}$ & $\begin{array}{l}\text { Geo- } \\
\text { metric } \\
\text { mean }\end{array}$ & $\begin{array}{c}\text { Geo- } \\
\text { metric } \\
\text { SD }\end{array}$ \\
\hline $\begin{array}{l}\text { Operators of the tar } \\
\text { distillation process }\end{array}$ & $\begin{array}{l}\text { Naphthalene } \\
\text { 1-Naphthol } \\
\text { 2-Naphthol }\end{array}$ & $\begin{array}{l}69 \\
51 \\
47\end{array}$ & $\begin{array}{l}0.773 \\
0.016 \\
0.012\end{array}$ & $\begin{array}{l}3.77 \\
3.28 \\
3.36\end{array}$ & $\begin{array}{l}\text { 1-Naphthol } \\
\text { 2-Naphthol }\end{array}$ & $\begin{array}{l}6.9 \\
2.1\end{array}$ & $\begin{array}{l}2.143 \\
1.788\end{array}$ & $\begin{array}{l}693.1 \\
264.4\end{array}$ & $\begin{array}{l}2.904 \\
2.724\end{array}$ & $\begin{array}{l}7.08 \\
2.33\end{array}$ & $\begin{array}{l}1.943 \\
1.698\end{array}$ \\
\hline $\begin{array}{l}\text { Operators of the naphthalene } \\
\text { oil distillation process }\end{array}$ & $\begin{array}{l}\text { Naphthaiene } \\
\text { 1-Naphthol } \\
\text { 2-Naphthol }\end{array}$ & $\begin{array}{l}33 \\
33 \\
33\end{array}$ & $\begin{array}{l}0.867 \\
0.034 \\
0.067\end{array}$ & $\begin{array}{l}4.22 \\
3.32 \\
2.66\end{array}$ & $\begin{array}{l}\text { 1-Naphthol } \\
\text { 2-Naphthol }\end{array}$ & $\begin{array}{l}4.8 \\
2.2\end{array}$ & $\begin{array}{l}2.114 \\
1.567\end{array}$ & $\begin{array}{l}548.8 \\
297.7\end{array}$ & $\begin{array}{l}3.083 \\
2.410\end{array}$ & $\begin{array}{l}6.21 \\
2.54\end{array}$ & $\begin{array}{l}2.057 \\
1.504\end{array}$ \\
\hline Unexposed workers & - & $\begin{array}{l}36 \\
17\end{array}$ & - & - & $\begin{array}{l}\text { 1-Naphthol } \\
\text { 2-Naphthol }\end{array}$ & $\begin{array}{l}0.09 \\
0.06\end{array}$ & $\begin{array}{l}1.022 \\
1.632\end{array}$ & $\begin{array}{l}7.8 \\
4.6\end{array}$ & $\begin{array}{l}2.069 \\
1.668\end{array}$ & $\begin{array}{l}0.07 \\
0.05\end{array}$ & $\begin{array}{l}2.063 \\
1.862\end{array}$ \\
\hline
\end{tabular}

a Number of workers for which the phenols were excreted above the analytical detection fimits.

range of $22.5-90.7 \%$ with the mean value of $64.8(\mathrm{SD}$ $61.3) \%$.

Significant differences $(\mathrm{P}<0.05)$ were found between the concentrations of 1- and 2-naphthols in the urine of the exposed workers (groups A and B) and the reference group (C).

The correlations between the time-weighted average naphthalene exposure and the 1- and 2-naphthols in the end-shift urine were examined by regression analysis. After logarithmic transformation, they had a linear form. In table 3 the parameters of the linear regression calculated for the observed values and values corrected against the specific gravity of urine are presented. Figures 3 and
4 present the linear regression curves for results corrected against the creatinine content in urine. The correlation coefficients for the dependence between the naphthol concentrations in urine and the naphthalene concentrations in the breathing-zone air were statistically significant at $\mathrm{P}<0.001$. However, they were relatively low, varying within the range of $0.64-0.75$ for 1-naphthol and $0.70-0.82$ for 2-naphthol. The correction of the metabolite level against creatinine or the specific gravity of urine did not increase the correlation coefficients (table 3 , figure 3$)$. A strong correlation $(r=0.76)$ was found between the summary concentration of naphthols in urine and air (see figure $4 \mathrm{C}$ ). 
Table 3. Correlation between naphthalene in air and 1 - and 2-naphthol in urine. [ $\alpha$ and $\beta=$ the slope and the intercept on the vertical axis of the calculated regression line according to the equation: $\log y=\alpha+\beta \log x$, where $x$ is the time-weighted average naphthalene concentration in breathing-zone air $\left(\mathrm{mg} / \mathrm{m}^{3}\right)$ and $\mathrm{y}$ is the concentration of the urine metabolite $(\mu \mathrm{mol} / \mathrm{l})$ for the observed values and the values corrected for specific gravity of urine $(1.024 \mathrm{~g} / \mathrm{ml}), r=$ correlation coefficient]

\begin{tabular}{|c|c|c|c|c|c|c|c|c|c|c|c|}
\hline \multirow[t]{2}{*}{ Group } & \multirow[t]{2}{*}{$\begin{array}{l}\text { Solvent } \\
\text { in air }\end{array}$} & \multirow[t]{2}{*}{$\begin{array}{l}\text { Metabolite } \\
\text { in urine }\end{array}$} & \multirow[t]{2}{*}{$\begin{array}{l}\text { Workers } \\
\text { (N) }\end{array}$} & \multicolumn{4}{|c|}{ Observed value } & \multicolumn{4}{|c|}{$\begin{array}{l}\text { Values corrected for specific gravity } \\
\text { of } 1.024 \mathrm{~g} / \mathrm{ml}\end{array}$} \\
\hline & & & & $\alpha$ & $\beta$ & $r^{2}$ & P-values & $\alpha$ & $\beta$ & $r^{2}$ & P-values \\
\hline $\begin{array}{l}\text { Operators of the tar } \\
\text { distillation process }\end{array}$ & $\begin{array}{l}\text { Naphthalene } \\
\text { Naphthalene }\end{array}$ & $\begin{array}{l}\text { 1-Naphthol } \\
\text { 2-Naphthol }\end{array}$ & $\begin{array}{l}69 \\
47\end{array}$ & $\begin{array}{r}0.01 \\
-0.39\end{array}$ & $\begin{array}{l}0.58 \\
0.52\end{array}$ & $\begin{array}{l}0.52 \\
0.67\end{array}$ & $\begin{array}{l}<0.001 \\
<0.001\end{array}$ & $\begin{array}{r}0.07 \\
-0.35\end{array}$ & $\begin{array}{l}0.50 \\
0.45\end{array}$ & $\begin{array}{l}0.41 \\
0.54\end{array}$ & $\begin{array}{l}<0.001 \\
<0.001\end{array}$ \\
\hline $\begin{array}{l}\text { Operators of the naphthalene } \\
\text { oil distillation process }\end{array}$ & $\begin{array}{l}\text { Naphthalene } \\
\text { Naphthalene } \\
\text { Naphthalene }\end{array}$ & $\begin{array}{l}\text { 1-Naphthol } \\
\text { 2-Naphthol } \\
\text { 1- and 2-Naphthol }\end{array}$ & $\begin{array}{l}33 \\
33 \\
33\end{array}$ & $\begin{array}{r}-0.05 \\
-0.41 \\
0.13\end{array}$ & $\begin{array}{l}0.6 \\
0.47 \\
0.53\end{array}$ & $\begin{array}{l}0.57 \\
0.66 \\
0.65\end{array}$ & $\begin{array}{l}<0.001 \\
<0.001 \\
<0.001\end{array}$ & $\begin{array}{r}0.01 \\
-0.37 \\
0.22\end{array}$ & $\begin{array}{l}0.55 \\
0.39 \\
0.46\end{array}$ & $\begin{array}{l}0.52 \\
0.49 \\
0.62\end{array}$ & $\begin{array}{l}<0.001 \\
<0.001 \\
<0.001\end{array}$ \\
\hline
\end{tabular}
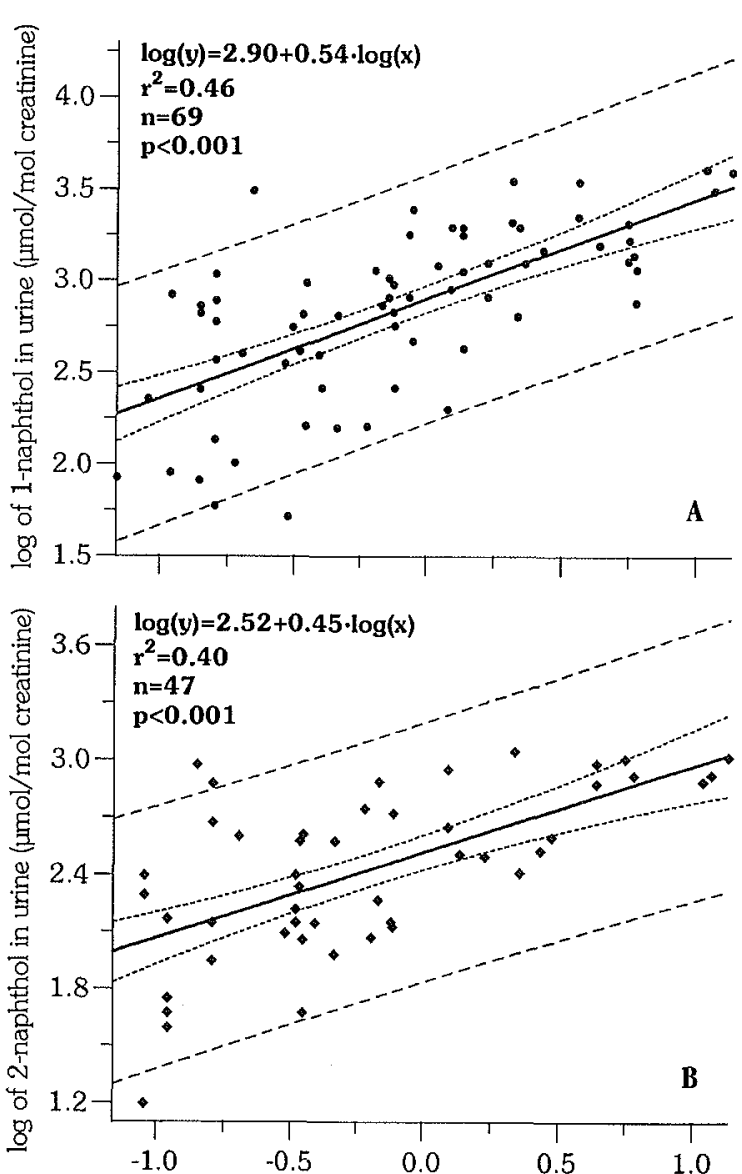

$\log$ of naphthalene in air $\left(\mathrm{mg} / \mathrm{m}^{3}\right)$

Figure 3. Relation between naphthalene in breathing-zone air and 1 naphthol in postshift urine $(A)$ and 2-naphthol in postshift urine $(B)$ of operators in the tar distillation process. $(-=$ calculated regression line, $-\cdots--=95 \% \mathrm{Cl}, \ldots . .=$ range of individual samples)

\section{Discussion}

The coal-tar industry is a major source of small amounts of naphthalene that are directly emitted to the environ-
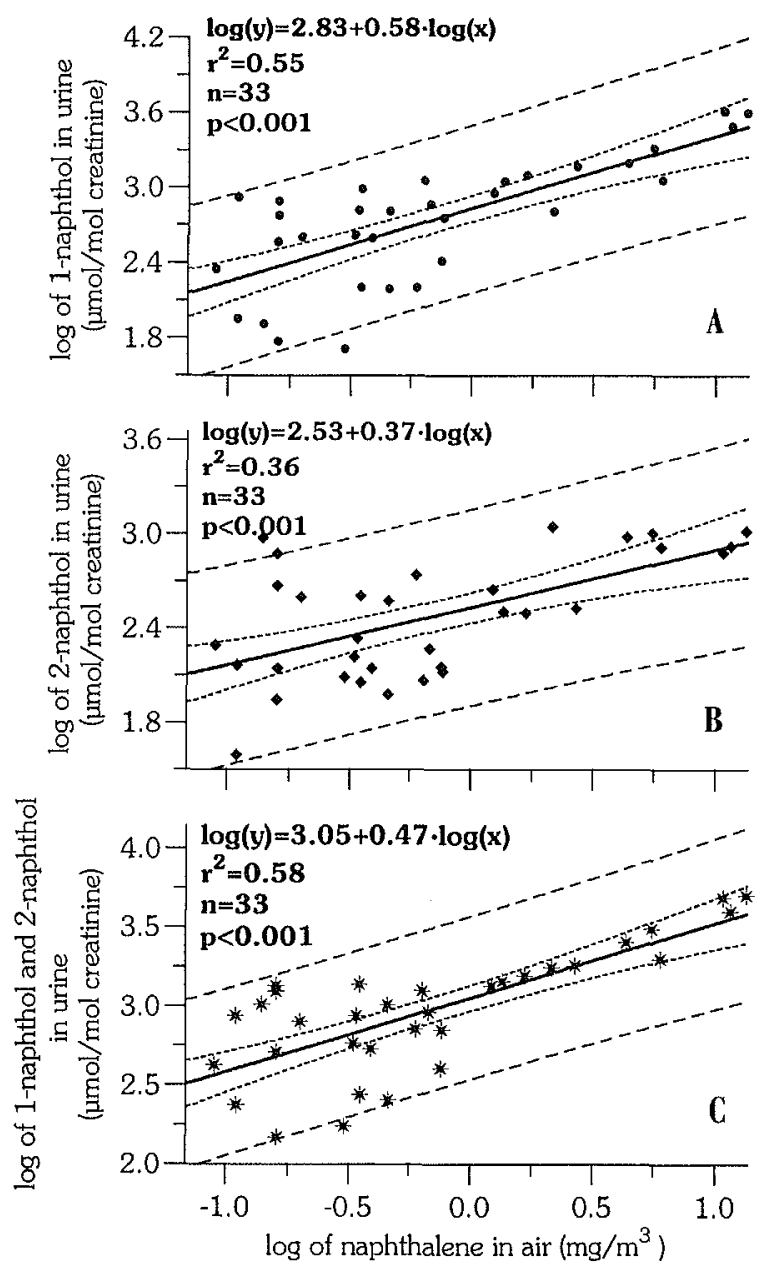

Figure 4. Relation between naphthalene in breathing-zone air and 1naphthol in postshift urine $(A)$, 2-naphthol in postshift urine $(B)$, and the sum of 1-naphthol and 2-naphthol in postshift urine (C) of operators in the naphthalene oil distillation process. $(-=$ calculated regression line, $----=95 \% \mathrm{Cl},-\ldots-$ - range of individual samples)

ment. This study shows that operators in the naphthalene oil and tar distillation processes are exposed to relatively low concentrations of naphthalene. In the breathingzone air the concentrations of naphthalene were below 
$12 \mathrm{mg} / \mathrm{m}^{3}$ and were relatively low in comparison with the permissible exposure levels. The threshold limit value (TLV) has been set at $10 \mathrm{ppm}\left(52 \mathrm{mg} / \mathrm{m}^{3}\right)(20)$. The National Institute for Occupational Safety and Health (NIOSH) (21) considers more than 500 ppm of naphthalene in air to be immediately dangerous to life or health. Bjørseth et al (22) have reported vapor levels of 1.1 to $11 \mu \mathrm{g} / \mathrm{m}^{3}$ in a coke plant. Higher levels would be anticipated in naphthalene-producing industries and naphthalene-using industries such as wood preserving, coal-tar production, and the production of dyes, inks and similar compounds (13).

Adsorbed naphthalene was determined by the method recommended by NIOSH (23), which calls for desorption of the charcoal with a carbon disulfide solution and quantification gas chromatographically. Naphthalene shows poor desorption efficiency at low loading. For higher efficiency NIOSH (23) recommends a minimum sampling volume of 1001 . In spite of the low desorption from charcoal, this method is the favored means of sampling naphthalene from air for analysis.

The biological monitoring of naphthalene provides a better estimation of the adsorbed substances than measurements of the corresponding contaminates in air because the skin can be the main route of exposure (16). Naphthalene metabolism is complex and leads to the formation of a wide assortment of hydroxylated derivatives, quinones, and conjugates of glucuronic acid, glutathione, and sulfate (24).

Immunological techniques are being developed for the identification of naphthalene mercapturic acid derivatives in urine (25) and naphthalene hemoglobin adducts in blood (26).

Traditionally, the most common method used for the biological monitoring of naphthalene exposure has been based on measuring a metabolite of naphthalene, usually urinary 1-naphthol. Some caution must be exercised in using 1-naphthol as a biomarker of naphthalene exposure in the general population because this metabolite is also excreted after exposure to the common insecticide carbaryl (27). Investigations by Connor et al (28) have shown that smoking can contribute to the excretion of 1 naphthol in urine, Recent studies have demonstrated that the maximum concentration of 1-naphthol in the urine of operators working with the naphthalene oil distillation process appears $1 \mathrm{~h}$ after the end of a shift (15). The 1naphthol concentration was the highest in the morning before the workday. Measurements taken at this time of day probably reflect the exposure on the previous day (16).

The present study attempted to evaluate the relation between naphthalene exposure and various recently developed biomarkers so that a biological exposure index corresponding to naphthalene exposure can be estimated. Our results show that most naphthalene is metabolized to
1- and 2-naphthol and 1,4-naphthoquinone (figure 2). Small amounts of 1-naphthol and 2-naphthol are excreted in the urine after the dermal application of naphthalene (4). In an earlier study it has been shown that there is a good statistical correlation between 1-naphthol excretion and naphthalene exposure in the concentration range of $0.2-6 \mathrm{mg} / \mathrm{m}^{3}$. This urinary metabolite can indicate exposure to both naphthalene and low concentrations of 1-naphthol during the naphthalene oil distillation process (15). Our study confirms a previous assumption that there is a correlation between the presence of naphthalene in air and the urinary excretion of 1-naphthol and 2-naphthol, which are two major oxygenated metabolites of naphthalene. Significant correlations between 1-naphthol or 2-naphthol and naphthalene exposure (figures 3 and 4) were found.

It is important to stress that the present study was carried out among workers in a coke plant. The workers were exposed to numerous other volatile compounds in addition to naphthalene (figure 1). Several aromatic hydrocarbons in tar and naphthalene oil are known to have either synergistic or antagonistic effects on coexposure to naphthalene. The GC-MS analysis of breathing-zone air showed that the coke plant workers employed in the naphthalene oil distillation process are simultaneously exposed to naphthalene, 1- and 2-methylnaphthalenes, dimethylnaphthalene isomers, trimethylnaphthalene (figure 1) and other compounds (Bieniek \& Kurkiewicz, unpublished results).

In conclusion, our results show the existence of low exposure to naphthalene, which is however qualitatively diversified in coke plants. Urinary 1-naphthol and 2naphthol seem to be useful biomarkers in the assessment of naphthalene exposure in a coke plant.

\section{Acknowledgments}

I am grateful to Professor T Wilczok for his general supervision of the experimental work. I would like to thank the Managing Board of the Zabrze Cokery Plant for their kind permission to continue my research and $\mathrm{Mr}$ S Kurkiewicz and Ms K Klimek for their kind help in the GC-MS measurements and statistical analyses.

\section{References}

1. International Agency for Research on Cancer (IARC). Indoor air. Lyon: IARC, 1993. IARC scientific publication on indoor concentrations of environmental carcinogens, vol 12, publication no 109.

2. Harden RA, Baetjer AM. Aplastic anemia following exposure to paradichlorobenzene and naphthalene. J Occup Med 1978;20:820-2. 
3. Shannon K, Buchanan GR. Severe hemolytic anemia in black children with glucose-6-phosphate dehydrogenase deficiency. Pediatrics 1982;70:364 9.

4. Turkall RM, Skowronski GA, Kadry AM, Abdel-Rahman MS. A comparative study of the kinetics and bioavailability of pure and soil-adsorbed naphthalene in dermally exposed male rats. Arch Environ Contam Toxicol 1994;26:504-9.

5. National Toxicology Program (NTP). Toxicology and carcinogenesis studies of naphthalene in $\mathrm{B} 6 \mathrm{C} 3 \mathrm{~F}_{1}$ mice (inhalation studies). Research Triangle Park (NC): US Department of Health and Human Services, National Institutes of Health, 1992. Technical report series, no 410 , publication no $92-$ 3141.

6. Adkins B Jr, Van Stee EW, Simmons JE, Eustis SL. Oncogenic response of strain A/I mice to inhaled chemicals. J Toxicol Environ Health 1986;17:311-22.

7. Wells PG, Wilson B, Lubek BM. In vivo murine studies on the biochemical mechanism of naphthalene cataractogenesis. Toxicol Appl Pharmacol 1989;99:466 - 73 .

8. Ojwang PJ, Ahmed-Jushuf IH, Abdullah MS. Naphthalene poisoning following ingestion of moth balls [case report]. East Afr Med J 1985;62:72-3.

9. Horning MG, Stillwell WG, Griffin GW, Tsang WS. Epoxide intermediates in the metabolism of naphthalene by the rat. Drug Metab Dispos 1980;8:404-14.

10. Stillwell WG, Horning MG, Griffin GW, Tsang W-S. Identification of new sulfur - containing metabolites of naphthalene in mouse urine. Drug Metab Dispos 1982;10:624-31.

11. Bakke J, Struble C, Gustafsson JA, Gustafsson B. Catabolism of premercapturic acid pathway metabolites of naphthalene to naphthols and methylthio-containing metabolites in rats. Proc Natl Acad Sci USA 1985;82:668 - 71 .

12. Murano H, Kojima M, Sasaki K. Differences in naphthalene cataract formation between albino and pigmented rat eyes. Ophthalmic Res 1993;25:16-22.

13. Agency for Toxic Substances and Disease Registry (ATSDR). Toxicological profile for naphthalene, 1-methylnaphthalene and 2-methylnaphthalene. Atlanta (GA): Department of Health and Human Services, 1995.

14. Xu GT, Zigler JS, Lon MF. Establishment of naphthalene cataract model in vitro. Exp Eye Res 1992;54:73 81 .

15. Bieniek $\mathrm{G}$. The presence of 1 -naphthol in the urine of industrial workers exposed to naphthalene. Occup Environ Med 1994; 51:357-9.

16. Heikkilä P, Luotamo M, Pyy L, Riihimäki. Urinary 1-naphthol and 1-pyrenol as indicators of exposure to coal tar products. Int Arch Occup Environ Health 1995;67:211-7.
17. Keiser JE, Kirby KW, Tremmel E. Reversed phase high performance liquid chromatographic separation of human phenolic metabolites of propoxur (Baygon), carbo-furan and carbaryl. J Chromatogr 1983;259:186-8.

18. Hansen AM, Omland O, Poulsen OM, Sherson D, Sigsgaard $\mathrm{T}$, Christensen JM, et al. Correlation between work processrelated exposure to polycyclic aromatic hydrocarbons and urinary levels of $\alpha$-naphthol, $\beta$-naphthylamine and 1-hydroxypyrene in iron foundry workers. Int Arch Occup Environ Health 1994;65:385-94.

19. Bieniek G. Simultaneous determination of phenol, cresol, $x y-$ lenol isomers and naphthols in urine by capillary gas chromatography. J Chromatogr B 1996;682:167-72.

20. American Conference of Governmental Industrial Hygienists (ACGIH) 1995-1996. Threshold limit values and biological exposure indices. Cincinnati (OH): ACGIH, 1996.

21. National Institute for Occupational Safety and Health (NI$\mathrm{OSH})$. NIOSH pocket guide to chemical hazards. Washington (DC): US Department of Health and Human Services, 1992. Publication no 158.

22. Bjørseth A, Bjørseth O, Fjeldstad PE. Polycyclic aromatic hydrocarbons in the work atmosphere: II. determination in a coke plant. Scand J Work Environ 1978:4:224-36.

23. National Institute for Occupational Safety and Health (NIOSH). Hydrocarbons, aromatic - method 1501. In: NIOSH manual of analytical methods. 4th ed. Cincinnati $(\mathrm{OH})$ : NIOSH, 1994.

24. Chern WH, Dauterman WC. Studies on the metabolism and excretion of 1-naphthol, 1-naphthyl- $\beta$-D-glucuronide and 1naphthyl- $\beta$-D-glucoside in the mouse. Toxicol Appl Pharmacol 1983;67:303-9.

25. Marco MP, Nasiri M, Kurth MJ, Hammock BB. Enzymelinked immunosorbent assay for the specific detection of the mercapturic acid metabolites of naphthalene. Chem Res Toxicol 1993;6:284-93.

26. Cho M, Jedrychowski R, Hammock B, Buckpitt A. Reactive metabolite binding to hemoglobin and albumin. Fundam Appl Toxicol 1994;22:26-33.

27. Benson WH, Dorough MW. Comparative ester hydrolysis of carbaryl and ethiofencarb in four mammalian species. Pest Biochem Physiol 1984;21:199-206.

28. Connor TH, Ramamujam VM, Ward JB Ir, Legator MS. The identification and characterization of a urinary mutagen resulting from cigarette smoke. Mutat Res 1983;113:161-72.

Received for publication: 14 April 1997 